\title{
BUDGETING AS A BASIC FINANCIAL PLANNING
}

Key words:

budgeting; enterprise; income; expenses; current financial planning; budgeting principles.
Buhai V. Z, Gorbynova A. V.

Zaporizhzhia National University

Ukraine, 69600, Zaporizhzhia, Zhukovsky str., 66

bugai_v_z@ukr.net,gor_an_v@ukr.net

ORCID 0000-0002-3568-1577

ORCID 0000-0001-6450-4740

Based on the strategic objectives of the enterprise, has been determined relevance of budgeting and has been identified as essential to the effective development of operation activities. It s proven, that budgeting - the process of organization the financial and economic management of economic entities, which based on the development of budget for responsibility centers and activities, monitoring of their implementation, analysis of budget anomalies and regulation of economic activity to harmonize and achieve results at all management levels. The rationale for the role of budgeting in financial planning is treated differently by scientists: establishment budget milestones without assigning lead; formation of the financial structure of an instrument of financial planning and controlling; that the budget is a management technology. It has been determined that budgeting, as a management technology, should include three interrelated constituent parts: technology (targets and standards, budget types, budget consolidation schemes, formats), organization (liability centers, budgeting and budgetary control regulations, distribution of roles and responsibilities between different management levels, slotting systems) and automation of financial calculation. Main causes of necessity for implementation budgeting in domestic enterprises are: lack of information on real costs, expenses and income in the enterprises; misuse of organization resources; significant financial loss; foreclosure crisis. Scientifically based budgeting principles established the practical application of which is a prerequisite for effective budgetary planning. The role of budgeting in financial planning was justified as well as its benefits for domestics' enterprises. A number of problems need to be solved to realize of benefits of enterprises budgeting, namely: economic, technical, organization, social and information.

\section{БЮДЖЕТУВАННЯ ЯК ОСНОВА ФІНАНСОВОГО ПЛАНУВАННЯ}

\author{
Бугай В. 3., Горбунова А. В. \\ Запорізький національний університет \\ Україна, 69600, м Запоріжжя, вул. Жуковського, 66
}

\section{Ключові слова:}

бюджетування; підприємство; доходи; витрати; поточне фінансове планування; принципи бюджетування.
Визначено актуальність бюджетування та встановлено, що воно необхідно для ефективного розвитку операційної діяльності, виходячи із стратегічних цілей підприємства. Обгрунтовано, що бюджетування - процес організації управління фінансово-господарською діяльністю суб'єктів господарювання, який грунтується на розробці бюджетів у розрізі центрів відповідальності та напрямів діяльності, організації контролю за їх виконанням, аналізу відхилень від бюджетних показників та регулюванні на цій основі господарської діяльності 3 метою узгодження й досягнення намічених результатів на всіх рівнях управління. Науковці по-різному підходять до обгрунтування ролі бюджетування у фінансовому плануванні: встановлення етапів бюджетування, не виокремлюючи провідної ланки; формування фінансової структури підприємства; як інструмент фінансового планування та контролю; що бюджетування - управлінська технологія. Встановлено, що бюджетування, як управлінська технологія, повинно включати три взаємопов'язані складові частини: технологію (цільові показники і нормативи, види бюджетів, схеми консолідації бюджетів, формати бюджетів), організацію (центри відповідальності, регламент бюджетування і бюджетного контролю, розподіл функцій і відповідальності між різними рівнями управління, система документообігу) і автоматизацію фінансових розрахунків. Основними причинами, що зумовлюють необхідність впровадження бюджетування на вітчизняних підприємствах $є$ : відсутність інформації про реальні витрати, видатки та надходження на підприємстві; нецільове використання ресурсів організації; значні фінансові втрати; криза неплатежів. Встановлено, науково обгрунтовані принципи бюджетування, практичне застосування яких $\epsilon$ необхідною умовою ефективності процесу бюджетного планування. Обгрунтовано роль бюджетування у фінансовому плануванні, а також переваги його впровадження на вітчизняних підприємствах. Щоб реалізувати переваги бюджетування, на підприємствах необхідно вирішити низку проблем, а саме: економічні; технічні; організаційні; соціальні; інформаційні. 


\section{Statement of the problem}

There is a need to improve product competitiveness and investment attractiveness of domestics enterprises in the context of Ukraine`s integration into European Community and markets competition increase. This makes it necessary for enterprises to build qualitatively new management systems, complied with global standards. Budgeting - is one of the progressive management technologies that promote economic efficiency.

Increased focus on budgeting is attributable to ensure survival end economic growth in the market environment of economic entities, it is reasonable to calculate planned incomes and expenses, profits, working capital and investment requirements, balance monetary flows and ensuring the necessary level of capacity to pay.

\section{Analysis of recent studies and publications}

Many domestic and foreign scientists conducted a study on enterprises budgeting. Thus, researchers I. A. Chayun and V. F. Srebrinsky focus on the development phases and implementation of budgeting systems [1]. However, it's not single out the leading element. I. B. Nemirovsky and I. A. Starozhukova [2] propose manage the enterprise through a balanced scorecard based on the budgetary planning and the formation of the financial structure of the enterprise, without stating what exactly is in the process of the implementing enterprise budgeting. A. V. Tyrinova observed that budgeting becomes an instrument of the internal financial planning and control [3]. In this way it`s not focus on its implementation. The scientist T. A. Pozhueva notes, that a number of conditions have to be involved to eliminate difficulties in the using of the budgeting, which arise in the initial stages of its introduction in the enterprise: determination of the objectives of the enterprise; establishing the need of introduction of intra-firm planning and the desirability of its use by a business unit [4]. There is no indication of how to overcome them. N. I. Rudik observes, that the budgeting - is a management technology to ensure that the strategic objectives of the enterprise are met [5]. However, without specifying these objectives.

So, there is no a unified approach among researches defining the role of budgeting in financial planning.

\section{Objectives of the article}

The purpose of the item is to identify and study the components of budgeting and the rationale for its role in enterprise financial planning.

\section{The main material of the research}

The budgeting - is the process of planning the future of an enterprise, which results are formalized by the system of budgets. The budgeting is generally done through operation planning, based on the strategic objectives of the enterprise.

The main objectives of the budgetary should be classified [6]:

- ensuring of current planning;

- coordination, cooperation and communication of enterprise units;

- $\quad$ support expenditure of enterprise;
- establishing a framework for the evaluation and monitoring of enterprise plans;

compliance with laws and contracts.

In the opinion of S.F.Golova, the budgeting should be understood as planning of future operations of enterprise and presentation of its results in the form of a budgeting system [7]. However, this interpretation of budgeting is somewhat limited, since budgeting is not only about budgeting, but also managing variances in incomeexpenditure.

In the view of B.P. Savchuk [6], budgetary and budget are identical concepts, related to the level and composition of costs, providing absorb these expense by financial resources from various sources. This interpretation of the nature of the period to be analyzed is more relevant to the essence of financial planning in an enterprise.

Scientists D.K.Shim and D.G. Siegel [8], the concept of budgeting is understood as a system of coordinated management of enterprise units. However, this formulation does not provide a clear understanding of the nature of budgeting, since it only addresses the organizational aspect of budgeting.

The researcher V. V. Burtsev [9], considers "budgeting" as a short-term planning system, monitoring of resources and performance, which can be accepted, but it is not entirely appropriate to limit budgeting to the short term.

There are other approaches to defining the concept of "budgeting". For example, Professors A.E. Kuzmin and A. H. Melnik [10], are understood "budgeting" as management technology.

In our opinion, the most justified interpretation of the essence "budgeting" given by S. Onishchenko, that budgeting is the process of organizing financial and economic activities of economic entities, based on budgeting by responsibility centers and activities and arrangements for monitoring their implementation, analysis of budget variances and regulation of economic activity on this basis to harmonize and achieve results at all levels of management [11].

We agree with V. E. Khutsky, V. V. Gamayunovir and Sizov T. V. [12], that budgeting as management technology should comprise three interrelated building blocks: technology, organization and financial automation (Fig. 1).

Thus, the budgeting process should include components, that will support the core enterprise management functional and the relationships of budgeting to an enterprise strategy and a description of the sequence of implementation of each component of budgeting, as management technology. Budgeting, as opposed to traditional management practices, influence on formation of financial resources more effectively, cash flows and financial performance due to prompt receipt of information, which plays a significant role in management decision-making. The main factors of the relevance of implementation that determine enterprise budgeting are: the need to find internal reserves to reduce production costs and implementing of production, rationale for optimal levels of financial resource consumption, optimizing tax payments and improving enterprise management; increased competition among enterprises, as 
a result, competitive advantage through improved management through the introduction of budgeting; integration of modern management systems and information technologies achieved through budgeting; the need to enhance the investment attractiveness of the organization, since foreign investors prefer self-financial in an enterprise with a high level of management [13].

Results of the survey of heads of domestic enterprise provide a list of the reasons that necessitated the introduction of budgetary systems or elements thereof (Table 1).

Table 1 - The reasons for introduction of budgetary systems or elements thereof in the domestic enterprises [10]

\begin{tabular}{|l|c|}
\hline \multicolumn{1}{|c|}{ Content of reasons } & Positive responses from managers, $\%$ \\
\hline 1.No information on real costs, expense and income of the enterprises & 35,2 \\
\hline 2. Misuse of organizational resources & 24,4 \\
\hline 3. Need to value all production and business transactions & 24,1 \\
\hline 4. Significant financial loss & 21,1 \\
\hline 5. Foreclosure crisis & 20,7 \\
\hline 6. Low fiscal discipline & 15,2 \\
\hline 7. Risk of bankruptcy & 9,7 \\
\hline 8. Low level of liquidity & 4,5 \\
\hline 9. Other reasons given by respondents & 1,5 \\
\hline
\end{tabular}

In most domestic enterprises cost management is relatively low, which is confirmed by the high unit costs, negative changes in expenditure trends and structure. For example, profitability of operational activities of industrial enterprises in Zaporizhzhya oblast, the average has not exceeded $5.0 \%$ in recent years. This situation demonstrates that, enterprises should adopt qualitatively new approaches to cost management to improve the efficiency of enterprises and achieve high financial results. The cost management at a qualitatively new level is possible through the introduction of budgeting in domestic enterprises.

The cost management efficiency is quite low in the most domestic enterprises, as evidenced by high unit costs and negative changes in expenditure trends and structure. For example, profitability of operations of industrial enterprises in Zaporizhzhya region, the average has not exceeded $5,0 \%$ in recent years. This situation indicates that innovative approaches to cost management should be introduced in enterprises, to improve the efficiency of enterprise operation and achieving high financial results. The cost management at a qualitatively new level is possible through the introduction of budgeting in domestic enterprises.

The studies points that scientifically based budgeting principles, the practical application of which is a prerequisite of efficiencies of the budgeting process are:

1. The principle of necessity - means compulsory application of plans in the performance of any activity. The principle of necessity is particularly important in a market economy, as its compliance with modern economic requirements of rationale resource management.

2. The principle of regularity - the budget should be drawn up and update within a certain temporal rhythm according to other plans of the enterprise.

3. The unity - defined by the need for a unified approach and the relationship between the plans of the enterprise and all its components and their functioning coordination. The unity of plans implies common plans and goals and also the interaction of different parts of the enterprise.
4. The principle of completeness consists in that the budget should cover all activities and all units of the enterprise. Different types of budgets can be developed within an enterprise. Depending on the facility, the coverage may be the total (consolidated) enterprise budget and the functional budgets of its individual units.

5. The principle of reality based on the need for prioritization of sales over production and taking into account resource constraints at the disposal of the enterprise.

6. The principle of integration due to the need for close interrelationship between different types and levels of budgets.

7. The principle of flexibility, which is permitted in the design and budgetary execution, the possibility of adjustability when internal or external operation conditions change.

8. The principle of economy implies that, between the result of budgeting itself and the cost of money and the time to implement it must be a rationale balance.

The development and implementation of enterprise budgeting requires considerable time, resources and effort. For example, a large transnational corporation, on average, $\$ 63,000$ is spent on budgeting for every $\$ 100$ million. And this is only the cost of the department that directly formulates the budgets excluding expense all entities involved in the process. The budget process averages takes 110 days. However, without financial planning enterprises incur significant losses. According to Russian experts, the absence of an accurate, objective and systematic information on the formation, use and distribution of the organization's resources results in losses that can amount to $20 \%$ of income [10].

The implementation of budgeting forces managers to quantitative indicators on cash flows their influence on the structure of assets and liabilities. And after three to four budget cycles, managers begin to forecast budget figures to several per cent accuracy. Specialists believe that the introduction of budgeting - is the primary system target, that should be established in case of financial problems, and for those enterprises whose development is undesirable, the formation of budgets would make it possible to identify the causes of the situation and determine areas of cost savings. 
The science and practice show that budgeting provides enterprises with such advantages as:

1. The budgeting formation requires research and determining expenditure of units or enterprises, its structure development. This should reflect the ideas of productive, innovative and social development based on the real capabilities of the enterprise. The budgeting process provides an opportunity for analysis and to assess existing and potential sources of income, identifies the need for external financing and so on. The budgeting helps to predict possible income and expenditure, gains and losses, assets and liabilities, solvency and liquidity, identify reserves and opportunities for cost reduction.

2. All unit costs are subject to real planning, control and regulation. This helps to prevent unnecessary costs and ensure the use of limited resources by purpose of developed budgets.

3. Allow for the creation of motivational mechanisms in the budgets themselves and related to their performance.

4. Predicting future financial problems in the company`s operations, its structural units due to changes in the internal or external functioning environments, that allows to take early anti-crisis measures.

5. The forecasting the impact of such measures as the tax base changes, relatively important in the structure of tax expenditure, capital expenditure, production reorientation, access to new markets, loans, attracting investment, winding down, etc. the budgeting allows for timely identification possible bottlenecks in the future activities of the enterprise, assess the economic impact of budget indicator deviations in a timely manner and make effective management decisions.

6. Managers examine the mechanism for optimizing costs and income in the structural subdivisions of the enterprise. Financial responsibility of enterprise within budgets, there is a need to scrutinize costs and the income of each of them, study of linkages between responsibility centers, creating conditions for achieving savings.

7. Strengthening financial discipline in the enterprise through increased accountability of managers and implementers for specific expenditures and revenues, expenditure and income and financial performance of the enterprise. The budgeting is not about incentives for oneoff financial results and for contributing to the growth of the enterprise among the participants in the market.

8. Creating opportunities to select the most promising areas of investment on the basis of the division of all types companies` business high-cost, low-cost and unprofitable.

9. Improving the financial performance of an enterprise be creating conditions enabling savings and earmarking of resources, reducing expenditure and increasing income.

10. Achieving the necessary level of capacity to pay by improving the management of cash flows through that the formation of consolidated or partial cash-flow budgets provides an opportunity to predict the future payment situation, prevents cash-flow gaps through timely mobilization of external sources of funding, changes in payment terms by suppliers and consumers, improved management of accounts receivable and payable.
11. Increasing the investment attractiveness of an enterprise by improving the quality of the management system. The budgeting allows making the enterprise "transparent" for investors, identifying profitable and unprofitable activities, highlighting linkages between units and management levels in the interprise, reflecting asset and liability structure, solvency and liquidity, etc.

12. Improved coordination level within enterprise by production of consolidated enterprise budgets, implemented trough the establishment of budgets for designated responsibilities centers at each management levels.

13. Improved quality of management decisions trough improved information management since budgets in an enterprise can be developed in different forms and types according to budgeting targets.

A number of issues need to be addressed to realize the stated benefits of enterprise budgeting:

- economic (lack of clearly defined objectives for the introduction of budgeting, "plan-fact" budget performance analysis system is not fully developed, problem of choice of methods of budgeting, problem of harmonization between economic, accounting and tax approaches recognition of income and expenditure, etc.);

- technical (lack of automated systems for budget procedures, problem of adaptation of foreign software products in the operating conditions of domestic enterprises, etc.);

- organizational (incorrectly designed budget structure of enterprise management, excessive detail of budget items, accounting complications, etc.);

- $\quad$ social (increased workload of workers, those involved in the budgeting process, insufficient qualifications of workers to work with budgetary systems, the existence of resistance to the introduction of budgeting on the part of employees of the enterprise, etc.);

- information (imperfect information management system for budgeting process in an enterprise, lack of ba normative and methodological framework for budgeting, lack of information processing system, etc.).

In summary, budgeting is an important tool for improving the effectiveness of development and the use of enterprise finance.

\section{Conclusions}

One of the main functions of the budgeting - is to plan activities includes a detailed business plan of activity of the enterprise. This function is intended to coordinate actions to achieve the objectives of the enterprise. However, the budget planning function allows any quantitative indicators of an enterprise's objectives to be complied, assess the extent to which they have been achieved, make a preliminary analysis of activities and future financial situation of the enterprise.

Through the evaluation of the responsibility centers and measures to meet the established targets analysis of the achievement of the objectives of the enterprise as a whole, and consequently, the impact of employee motivation on the degree to which the objectives of the enterprise are achieved. 


\section{References}

1. Chayun, I.A., Srebrinsky, V.F. (2017). Problemy formyrovanye systemy byudzhetuvannya diyal'nosti pidpryyemstva. [Problems of formation of the system of budgeting of activity of the enterprise]. Ekonomika i suspil'stvo. Economy and society, №9, 705 - 802 [in Ukrainian].

2. Nemirovskiy, I.B., Starozhukov, I.A. (2006). Byudzhetuvannya. Vid stratehiyi do byudzhetu - pokrokove kerivnytstvo. [Budgeting. From strategy to budget - a step-by-step guide]. Moscow: Publishing House «Williams» [in Russian].

3. Tyrinov, A.V. (2019). Orhanizatsiya byudzhetuvannya na pidpryyemstvi yak chastyna upravlins'koho obliku [Organization of budgeting at the enterprise as part of management accounting]. Naukovyy visnyk Khersons'koho derzhavnoho universytetu. Ekonomichni nauky - Kherson State University Bulletin. Economic Sciences, 34, 149-152 [in Ukrainian].

4. Pozhueva, T.A. (2017). Byudzhetuvannya yak napryamok udoskonalennya systemy upravlinnya diyal'nistyu pidpryyemstv [Budgeting as a direction of improving the management system of enterprises]. Bulletin of Economic Science of Ukraine, 1, 73-77 [in Ukrainian].

5. Rudik, N.I. (2018). Rozvytok byudzhetuvannya yak marketinhovoyi upravlins'koyi tekhnolohiyi. [Development of budgeting as a marketing management technology]. Hlobal'ni ta natsional'ni problemy ekonomiky - Global and national economic problems, 21, 392-395 [in Ukrainian].

6. Golov, S.F (2004). Upravlins'kyy oblik: pidruchnyk - 2-he vyd [ Management accounting: textbook - 2nd ed]. Kyiv: Libra [in Ukrainian].

7. Savchuk, B.P. (2008). Praktychna entsyklopediya. Finansovyy menedzhment. 3-e yzd. [Practical encyclopedia. Financial management. 3rd ed]. Kiev: Companion Group [in Ukrainian].

8. Shim, D. K., Siegel, D. G. (2001). Osnovy komertsiynoho byudzhetuvannya. pokrokove kerivnytstvo [The basics of commercial budgeting. Step by step guide]. Moscow: Azbuka [in Russian].

9. Burtsev, V.V. (2005). Cherez byudzhetuvannya do efektyvnoho menedzhmentu [Through budgeting to effective management]. Financoviy menedzhment - Financial management, 1, 33-40 [in Russian].

10. Kuzmin, A.E., Melnik, A.H. (2008). Byudzhetuvannya na pidpryyemstvi: navch. posib [Budgeting at the enterprise: textbook. way]. Kyiv: Condor, 312 [in Ukrainian].

11. Onishchenko, S. (2006). Byudzhetuvannya v systeme finansovoho upravlinnya pidpryyemstvom. [Budgeting in the system of financial management of the enterprise]. Bukhhalters'kyy oblik i audit - Accounting and Auditing, 6, 42-50 [in Ukrainian].

12. Khutsky, V.E. Gamayunov, V.V., Sizova, T.V. (2006). Vnutrifirmove byudzhetuvannya: Nastil'na knyha z postanovky finansovoho planuvannya [Intrafirm Budgeting: A Handbook for Setting Financial Planning]. Moscow: Finance and Statistics [in Russian].

13. Shapiro, J. (2006). Modelyuvannya lantsyuha postavok [Supply chain modeling]; per. from English ed. Lukinsky, V.S. SPb. : Peter [in Russian]. 